\title{
Safety of Drugs during Pregnancy and Breastfeeding in Cystic Fibrosis Patients
}

\author{
Alice Panchaud ${ }^{\mathrm{a}}$ Ermindo R. Di Paolo $^{\mathrm{b}}$ Angela Koutsokera $^{\mathrm{c}}$ \\ Ursula Winterfeld $^{d}$ Etienne Weisskopf ${ }^{a}$ David Baud ${ }^{\mathrm{e}}$ Alain Sauty ${ }^{\mathrm{c}}$ \\ Chantal Csajka ${ }^{a}$

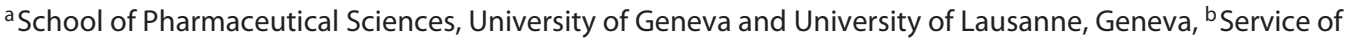 \\ Pharmacy, Department of Laboratory, 'Service of Pneumology, Department of Medicine, ${ }^{\mathrm{d}}$ STIS and Division \\ of Clinical Pharmacology, and ${ }^{\mathrm{e}}$ Materno-Fetal and Obstetrics Research Unit, Department of Gynecology and \\ Obstetrics, University Hospital of Lausanne, Lausanne, Switzerland
}

\section{Key Words}

Cystic fibrosis · Pregnancy $\cdot$ Lactation $\cdot$ Teratogen $\cdot$ Fetal risk

\section{Abstract}

Health management of cystic fibrosis (CF) patients should be maximized during pregnancy and breastfeeding because of its significant impact on the maternal and newborn outcomes. Thus, numerous drugs will have to be continued during pregnancy and lactation. Most of the drugs representing CF treatment lines cross the placenta or are excreted into human milk. Research addressing the risks and benefits of drugs used in CF patients during pregnancy and lactation is often incomplete or challenged by limited methodology, which often leads to conflicting or inconclusive results. Yet, potential treatment benefits for CF pregnant patients most often outbalance potential risks for the unborn child.

(c) 2016 S. Karger AG, Basel

\section{Introduction}

Median survival of patients suffering from cystic fibrosis (CF) has dramatically improved over the last decades, due to treatment and nutrition optimization. With increasing life expectancy, more and more women with CF wish to conceive. In contrast to males, the majority of females with CF have near-normal fertility, despite possible ovulation disturbances in patients with more severe disease [1].

About 240 pregnancies in CF patients are reported annually to the US Cystic Fibrosis Foundation Registry [2]. Furthermore, data from the US Nationwide Inpatient Sample showed a significant linear increase in the number of women with CF at delivery, going from 2.99 to 9.84 per 100,000 deliveries over the 2000-2010 period [3]. Proposed prognostic markers for pregnancy and fetal outcomes are lung function parameters (before and during pregnancy), overall nutritional status, CF-related diabetes and post-lung transplantation status [4-6]. Several studies have reported favorable maternofetal outcomes during and following pregnancy in women with $\mathrm{CF}$,

\section{KARGER}

E-Mail karger@karger.com www.karger.com/res
2016 S. Karger AG, Basel

$0025-7931 / 16 / 0914-0333 \$ 39.50 / 0$
Alice Panchaud, $\mathrm{PhD}$

Groupe de Pharmacie hospitalière \& clinique, Section des Sciences Pharmaceutiques, Université de Genève, Université de Lausanne Bureau BU/17-01/191, Av. du Bugnon 17, CH-1011 Lausanne (Switzerland) E-Mail alice.panchaud@chuv.ch 
whereas others described adverse outcomes. According to Patel et al. [7], women with CF are at increased risk of death, infectious morbidity, acute renal failure, preterm labor among other obstetric complications and require more mechanical ventilation. While pregnancy and motherhood do not appear to accelerate disease progression up to 11 years after pregnancy, they are linked to a higher frequency of illness-related medical visits, pulmonary exacerbations, and a decrease in some domains of quality of life [3].

$\mathrm{CF}$ is a multisystem disease that affects primarily the respiratory and the digestive systems, and most patients require chest physiotherapy, nutritional supplements, pancreatic enzymes, mucolytics, long-term oral and nebulized antibiotics [8], frequent courses of intravenous antibiotics and immunosuppressive drugs after transplantation, most of which will have to be continued during pregnancy. Because of its significant impact on obstetrical and neonatal outcomes, health management of CF patients should be maximized and should include preconceptionally an accurate medication review for the reassessment of each medication safety and effectiveness in the light of the upcoming pregnancy. This review offers an evaluation of up-to-date safety data during pregnancy and lactation of the most current drugs used in CF patients, providing healthcare professionals with a comprehensive review for decision making.

\section{Drugs in Pregnancy and Breastfeeding}

Drugs can interfere with a variety of developmental and reproductive processes causing infertility, chromosomal and genetic disorders, spontaneous abortions, intrauterine deaths, prematurity, low birth weight, birth defects and functional disorders [9]. Most drugs have a low molecular weight (600-800 Da) and are therefore able to cross the placenta. Organogenesis, which takes place between 20 and 70 days after the first day of the last menstruation period, is the critical period for the induction of structural malformations [9]. During the fetal period, drugs can induce growth restriction, some forms of structural malformations, fetal death, functional impairment, and transplacental carcinogenesis [9]. Prenatal and early postnatal exposure to drugs can lead to behavioral, reproductive, endocrine, immune, and various other physiological function impairments [9]. Drug exposure through human breast milk rarely achieves significant doses in the infant, and interferences will depend on the infant's ability to eliminate the drug and infant's sensitivity to the pharmacological effects [10]. The clinically most relevant parameter available to evaluate the level of drug exposure of the infant through breast milk is the relative infant dose (RID). RID is a weight-normalized parameter calculated by dividing the dose of drug ingested via milk $(\mathrm{mg} / \mathrm{kg} /$ day) by the mother's dose in $\mathrm{mg} / \mathrm{kg} /$ day.

The evaluation of risks and benefits of drugs during pregnancy and lactation is often incomplete. It is most often based on case reports, case series and cohort studies, while evidence-based randomized controlled trials are rarely used in pregnant and lactating women, mainly for ethical reasons. Furthermore, the low prevalence of most of the drug-related risks requires very large sample sizes to formally establish the safety of a drug during pregnancy or lactation, which are often not available. This situation frequently leads to conflicting or inconclusive information making therapeutic decisions difficult for clinicians.

\section{Drugs Used in CF Patients}

\section{Respiratory System}

Pulmonary manifestations remain the major cause of morbidity and mortality in CF patients. Infection control, improvement of airway clearance, and bronchodilation are the cornerstones of CF management [11].

\section{Antibiotics}

Pregnancy. Antibiotics are the major components of CF treatment and are administered chronically (e.g. inhaled antibiotics, macrolides used for their immunomodulatory properties) or intermittently to prevent, eradicate, control or treat respiratory infections $[12,13]$. Due to increased antibiotic clearance and distribution, higher doses are usually administered to CF patients, and a combination of antibiotics is often necessary due to the presence of multiple or multiresistant microorganisms.

Most antibiotics are safe for use in pregnancy (table 1). All the antibiotics for which the placental transfer has been studied can be detected in the amniotic fluid [14]. Penicillins, well-documented cephalosporins (e.g. cefaclor, cefuroxim, ceftriaxon) and macrolides (azithromycin, clarithromycin, erythromycin) are first-line treatments during pregnancy for sensible pathogens such as Staphylococcus aureus or Haemophilus influenzae [9, 1517]. Antipseudomonal penicillins, including piperacillin, piperacillin-tazobactam, temocillin, and less documented cephalosporins (ceftazidime, cefepime), carbapenems (meropenem, imipenem, ertapenem), monobactam (az- 
Table 1. Antibiotics in pregnant and lactating CF patients

\begin{tabular}{|c|c|c|c|}
\hline \multirow[t]{2}{*}{ Drug } & \multicolumn{3}{|l|}{ Pregnancy } \\
\hline & safety data & compatibility & recommendations \\
\hline Penicillins & $\begin{array}{l}\text { Numerous } \\
\text { human data }\end{array}$ & $\begin{array}{l}\text { Drug of choice } \\
\text { in pregnant } \mathrm{CF} \\
\text { patients }\end{array}$ & $\begin{array}{l}\text { If necessary, combination therapy with } \\
\text { a betalactamase inhibitor can be used } \\
\text { (e.g. clavulanic acid, tazobactam) }\end{array}$ \\
\hline
\end{tabular}

Lactation

level of compatibility recommendations exposure

RID $<2 \%$ Drug of choice Intravenous use often linked to in lactating CF poor oral bioavailability and patients subsequent systemic exposure in the suckling infant May alter gastrointestinal flora of the suckling infant

\begin{tabular}{|c|c|c|c|}
\hline $\begin{array}{l}\text { Cephalo- } \\
\text { sporins }\end{array}$ & $\begin{array}{l}\text { Numerous } \\
\text { human data }\end{array}$ & $\begin{array}{l}\text { Drug of choice } \\
\text { in pregnant } \mathrm{CF} \\
\text { patients }\end{array}$ & $\begin{array}{l}\text { If equally effective, well-established } \\
\text { compounds of the class should be } \\
\text { preferred (e.g. cefaclor, cefuroxim, } \\
\text { ceftriaxon) }\end{array}$ \\
\hline
\end{tabular}

RID $<2 \%$ Drug of choice Intravenous use often linked to in lactating CF poor oral bioavailability and patients subsequent systemic exposure in the suckling infant May alter gastrointestinal flora of the suckling infant

\begin{tabular}{|c|c|c|c|c|c|}
\hline $\begin{array}{l}\text { Carba- } \\
\text { penems }\end{array}$ & $\begin{array}{l}\text { Limited } \\
\text { human data }\end{array}$ & $\begin{array}{l}\text { Second-line } \\
\text { treatment in } \\
\text { pregnant CF } \\
\text { patients }\end{array}$ & $\begin{array}{l}\text { Imipenem and meropenems should be } \\
\text { used only in the absence of a safer } \\
\text { alternative }\end{array}$ & RID < $2 \%$ & $\begin{array}{l}\text { Second-line } \\
\text { treatment in } \\
\text { lactating CF } \\
\text { patients }\end{array}$ \\
\hline
\end{tabular}

Poor oral bioavailability and subsequent systemic exposure in the suckling infant

If effective, the most documented compounds of the class should be preferred (e.g. imipenem)

\begin{tabular}{|c|c|c|c|c|c|c|}
\hline $\begin{array}{l}\text { Mono- } \\
\text { bactam }\end{array}$ & $\begin{array}{l}\text { Limited } \\
\text { human data }\end{array}$ & $\begin{array}{l}\text { Second line } \\
\text { treatment in } \\
\text { pregnant CF } \\
\text { patients }\end{array}$ & $\begin{array}{l}\text { Aztreonam should be used only in the } \\
\text { absence of a safer alternative }\end{array}$ & RID $<2 \%$ & $\begin{array}{l}\text { Second-line } \\
\text { treatment in } \\
\text { lactating CF } \\
\text { patients }\end{array}$ & Poor oral bioavailability \\
\hline Macrolides & $\begin{array}{l}\text { Numerous } \\
\text { human data for } \\
\text { azithromycin, } \\
\text { clarithromycin, } \\
\text { erythromycin }\end{array}$ & $\begin{array}{l}\text { Drug of choice } \\
\text { in pregnant } \mathrm{CF} \\
\text { patients }\end{array}$ & $\begin{array}{l}\text { If equally effective, well-established } \\
\text { compounds of the class should be } \\
\text { preferred (e.g. azithromycin, } \\
\text { clarithromycin, erythromycin) } \\
\text { Other macrolides should be used only } \\
\text { in the absence of a safer alternative }\end{array}$ & RID $<2 \%$ & $\begin{array}{l}\text { Drug of choice } \\
\text { in lactating CF } \\
\text { patients }\end{array}$ & $\begin{array}{l}\text { If effective, the most documented } \\
\text { compounds of the class should be } \\
\text { preferred (i.e. azithromycin, } \\
\text { clarithromycin, erythromycin) }\end{array}$ \\
\hline Quinolones & $\begin{array}{l}\text { Numerous } \\
\text { human data for } \\
\text { norfloxacin and } \\
\text { ciprofloxacin }\end{array}$ & $\begin{array}{l}\text { Second-line } \\
\text { treatment in } \\
\text { pregnant CF } \\
\text { patients }\end{array}$ & $\begin{array}{l}\text { Norfloxacin and ciprofloxacin can be } \\
\text { used in the absence of a safer } \\
\text { alternative }\end{array}$ & RID > 5\% & $\begin{array}{l}\text { Second-line } \\
\text { treatment in } \\
\text { lactating CF } \\
\text { patients }\end{array}$ & $\begin{array}{l}\text { Theoretical risk of irreversible } \\
\text { damage to joint cartilage } \\
\text { If effective, the most documented } \\
\text { compounds of the class should be } \\
\text { preferred (i.e. ciprofloxacin) } \\
\text { Local use is safe for the breastfed } \\
\text { infant }\end{array}$ \\
\hline $\begin{array}{l}\text { Amino- } \\
\text { glycosides }\end{array}$ & $\begin{array}{l}\text { Limited human } \\
\text { data }\end{array}$ & $\begin{array}{l}\text { To be used } \\
\text { with caution }\end{array}$ & $\begin{array}{l}\text { Should be used only in life-threatening } \\
\text { infections because of their limited risk } \\
\text { of fetal oto- and nephrotoxicity } \\
\text { Therapeutic drug monitoring should } \\
\text { be performed to prevent toxicity and } \\
\text { inefficiency of the treatment } \\
\text { Inhaled tobramycin can be used during } \\
\text { pregnancy }\end{array}$ & RID $<2 \%$ & $\begin{array}{l}\text { Second-line } \\
\text { treatment in } \\
\text { lactating CF } \\
\text { patients }\end{array}$ & $\begin{array}{l}\text { Poor oral bioavailability } \\
\text { After intravenous use, avoid } \\
\text { breastfeeding during the } 2 \mathrm{~h} \\
\text { following the injection (maximal } \\
\text { concentration) } \\
\text { Inhaled tobramycin is safe for the } \\
\text { breastfed infant }\end{array}$ \\
\hline $\begin{array}{l}\text { Tetra- } \\
\text { cyclines }\end{array}$ & $\begin{array}{l}\text { Numerous } \\
\text { human data for } \\
\text { doxycycline }\end{array}$ & $\begin{array}{l}\text { To be used } \\
\text { with caution }\end{array}$ & $\begin{array}{l}\text { Doxycycline can be used in the absence } \\
\text { of a safer alternative until week } 15 \text { of } \\
\text { pregnancy } \\
\text { Avoid after week } 15 \text { due to the risk of } \\
\text { dental discoloration or growth } \\
\text { inhibition of the long bones }\end{array}$ & RID > $\% \%$ & $\begin{array}{l}\text { To be used } \\
\text { with caution }\end{array}$ & $\begin{array}{l}\text { Prolonged use ( }>3 \text { weeks) is not } \\
\text { advised because of dental } \\
\text { discoloration. Short term use }(<3 \\
\text { weeks) is compatible with } \\
\text { breastfeeding } \\
\text { Most tetracyclines bind to calcium, } \\
\text { thus inhibiting their absorption by } \\
\text { the suckling infant (doxycycline } \\
\text { binds less) }\end{array}$ \\
\hline
\end{tabular}

Safety of Drugs during Pregnancy and Breastfeeding in CF Patients 
Table 1 (continued)

\begin{tabular}{|c|c|c|c|c|c|c|}
\hline \multirow[t]{2}{*}{ Drug } & \multicolumn{3}{|l|}{ Pregnancy } & \multicolumn{3}{|l|}{ Lactation } \\
\hline & safety data & compatibility & recommendations & $\begin{array}{l}\text { level of } \\
\text { exposure }\end{array}$ & compatibility & recommendations \\
\hline Colistin & $\begin{array}{l}\text { Limited human } \\
\text { data }\end{array}$ & $\begin{array}{l}\text { To be used } \\
\text { with caution }\end{array}$ & $\begin{array}{l}\text { Intravenous use should be reserved for } \\
\text { life-threatening infections } \\
\text { Inhaled colistin can be used during } \\
\text { pregnancy }\end{array}$ & $\begin{array}{l}\text { RID } \\
\text { unknown }\end{array}$ & $\begin{array}{l}\text { Second-line } \\
\text { treatment in } \\
\text { lactating CF } \\
\text { patients }\end{array}$ & $\begin{array}{l}\text { Inhaled colistin is safe for the } \\
\text { breastfed infant }\end{array}$ \\
\hline $\begin{array}{l}\text { Sulfon- } \\
\text { amides }\end{array}$ & $\begin{array}{l}\text { Numerous } \\
\text { human data }\end{array}$ & $\begin{array}{l}\text { Second-line } \\
\text { treatment in } \\
\text { pregnant CF } \\
\text { patients }\end{array}$ & $\begin{array}{l}\text { During the first trimester, high dose or } \\
\text { long-term use of sulfonamides, such as } \\
\text { sulfamethoxazol-trimethoprim } \\
\text { combined with a folate antagonist (e.g. } \\
\text { trimethoprim) should be associated } \\
\text { with folic acid intake ( } 1-5 \mathrm{mg} / \text { day), } \\
\text { even though evidence is lacking to } \\
\text { support its efficacy } \\
\text { Sulfonamide use until birth can be } \\
\text { associated with a rise in bilirubin, } \\
\text { especially in premature neonates }\end{array}$ & $\begin{array}{l}\text { RID >5\% } \\
\text { for trime- } \\
\text { thoprim }\end{array}$ & $\begin{array}{l}\text { Second-line } \\
\text { treatment in } \\
\text { lactating CF } \\
\text { patients }\end{array}$ & $\begin{array}{l}\text { In the absence of safer alternative, } \\
\text { the most documented compounds } \\
\text { of the class should be preferred } \\
\text { (i.e. cotrimoxazole) }\end{array}$ \\
\hline $\begin{array}{l}\text { Clinda- } \\
\text { mycin }\end{array}$ & $\begin{array}{l}\text { Numerous } \\
\text { human data }\end{array}$ & $\begin{array}{l}\text { Second-line } \\
\text { treatment in } \\
\text { pregnant CF } \\
\text { patients }\end{array}$ & $\begin{array}{l}\text { Should be used only in the absence of a } \\
\text { safer alternative }\end{array}$ & RID <2\% & $\begin{array}{l}\text { Second-line } \\
\text { treatment in } \\
\text { lactating CF } \\
\text { patients }\end{array}$ & $\begin{array}{l}\text { Should be used only in the absence } \\
\text { of a safer alternative }\end{array}$ \\
\hline
\end{tabular}

treonam), can be safely used intravenously for Pseudomonas exacerbation.

Clindamycin, sulfonamides, trimethoprim, and cotrimoxazole are antibiotics of second choice in pregnan$c y$, and can be used when first-line antibiotics are ineffective or in case of allergy $[9,15]$. In case of long-term firsttrimester use of sulfonamides with a folate antagonist (e.g. trimethoprim), increased folic acid intake (1-5 mg/ day) is recommended, even though evidence is lacking to support its efficacy in preventing teratogenic effects $[9$, 17]. When sulfonamides are used until birth, a rise in bilirubin may be observed, especially in premature infants [9]. Tetracyclines have not been associated with an increased risk of malformations [18]. However, they can cause tooth discoloration and inhibition of bone growth if used after the 15th week of pregnancy due to binding to calcium ions $[9,15,17]$. Aminoglycosides carry a small risk of fetal nephro- and ototoxicity $[9,17,19]$. Therefore, their intravenous use should be reserved for life-threatening infections. Dose adjustment by therapeutic drug monitoring in pregnant CF patients is recommended with gentamicin, amikacin and tobramycin for efficacy and safety optimization in pregnancy [20].

Inhaled tobramycin is associated with minimal risks because of the limited systemic absorption. Quinolones have been associated with irreversible damage of joint cartilages in young animals treated directly (i.e. none resulting from in utero exposure). This has never been observed after in utero exposure to quinolones in humans $[18,21,22]$. In the absence of alternatives, the well-documented norfloxacin and ciprofloxacin should be preferred. Because of the lack of security data in pregnancy, intravenous colistin should be reserved for life-threatening infections, while its limited systemic absorption after inhalation limits the risks [9].

Breastfeeding. Most antibiotics are excreted into breast milk in very small amounts (table 1). A transient effect on the infants' stool consistency is the most frequently observed adverse event in infants exposed to antibiotics via breast milk [23]. Antibiotics discussed below are compatible with breastfeeding. Penicillins, cephalosporins and macrolides are first-line treatments during lactation $[9$, 17]. A short-time therapy with tetracyclines is possible ( $<3$ weeks), while clindamycin, sulfonamides, colistin and quinolones should only be used in CF lactating women when first-line antibiotics are ineffective. As a result of their poor oral bioavailability, carbapenems, monobactams or aminoglycosides are probably safe for the breastfed infant after maternal intravenous administration. Inhaled use of antibiotics is compatible with breastfeeding [24]. 
Table 2. Antifungal and antiviral agents in pregnant and lactating CF patients

\begin{tabular}{|c|c|c|c|c|c|c|}
\hline \multirow[t]{2}{*}{ Drug } & \multicolumn{3}{|l|}{ Pregnancy } & \multicolumn{3}{|l|}{ Lactation } \\
\hline & safety data & compatibility & recommendations & $\begin{array}{l}\text { level of } \\
\text { exposure }\end{array}$ & compatibility & recommendations \\
\hline Azole & $\begin{array}{l}\text { Numerous } \\
\text { human data for } \\
\text { fluconazole and } \\
\text { itraconazole; } \\
\text { no human data } \\
\text { for posaconazole } \\
\text { and voriconazole }\end{array}$ & $\begin{array}{l}\text { To be used } \\
\text { with caution }\end{array}$ & $\begin{array}{l}\text { Craniofacial, skeletal and cardiac } \\
\text { malformations after high-dose ( } 400-800 \\
\text { mg daily) and long-term therapy with } \\
\text { fluconazole have been reported in } \\
\text { humans } \\
\text { In the absence of safer alternative, } \\
\text { fluconazole and itraconazole can be used } \\
\text { for short-term therapy at low dose }\end{array}$ & $\begin{array}{l}\text { RID }>15 \% \\
\text { for } \\
\text { fluconazole }\end{array}$ & $\begin{array}{l}\text { To be used } \\
\text { with caution }\end{array}$ & $\begin{array}{l}\text { In the absence of safer } \\
\text { alternative, the most } \\
\text { documented compounds of the } \\
\text { class should be preferred (i.e. } \\
\text { fluconazole) } \\
\text { Local use is safe for the } \\
\text { breastfed infant }\end{array}$ \\
\hline $\begin{array}{l}\text { Ampho- } \\
\text { tericin B }\end{array}$ & $\begin{array}{l}\text { Limited human } \\
\text { data }\end{array}$ & $\begin{array}{l}\text { To be used } \\
\text { with caution }\end{array}$ & $\begin{array}{l}\text { Intravenous use should be reserved for } \\
\text { life-threatening infections } \\
\text { Possible placental accumulation } \\
\text { Oral or topical use is acceptable. }\end{array}$ & $\begin{array}{l}\text { RID } \\
\text { unknown }\end{array}$ & $\begin{array}{l}\text { Second-line } \\
\text { treatment in } \\
\text { lactating CF } \\
\text { patients }\end{array}$ & $\begin{array}{l}\text { Probably limited systemic } \\
\text { absorption in the breastfed } \\
\text { infant due to poor oral } \\
\text { bioavailability } \\
\text { Topical or oral use is safe for } \\
\text { the breastfed infant }\end{array}$ \\
\hline $\begin{array}{l}\text { Nystatin } \\
\text { (topical or } \\
\text { oral use) }\end{array}$ & $\begin{array}{l}\text { Limited human } \\
\text { data; limited } \\
\text { systemic } \\
\text { absorption }\end{array}$ & $\begin{array}{l}\text { Drug of choice } \\
\text { in pregnant } \mathrm{CF} \\
\text { patients }\end{array}$ & & $\begin{array}{l}\text { RID } \\
\text { unknown }\end{array}$ & $\begin{array}{l}\text { Drug of } \\
\text { choice in } \\
\text { pregnant CF } \\
\text { patients }\end{array}$ & $\begin{array}{l}\text { Poor oral bioavailability } \\
\text { Topical or oral use is safe for } \\
\text { the breastfed infant }\end{array}$ \\
\hline Oseltamivir & $\begin{array}{l}\text { Numerous } \\
\text { human data }\end{array}$ & $\begin{array}{l}\text { Drug of choice } \\
\text { in pregnant } \mathrm{CF} \\
\text { patients }\end{array}$ & $\begin{array}{l}\text { First choice if influenza antiviral } \\
\text { therapy is indicated }\end{array}$ & RID <0.5\% & $\begin{array}{l}\text { Drug of } \\
\text { choice in } \\
\text { lactating CF } \\
\text { patients }\end{array}$ & $\begin{array}{l}\text { First choice if influenza } \\
\text { antiviral therapy is indicated }\end{array}$ \\
\hline
\end{tabular}

\section{Antifungals}

Although invasive fungal infections are infrequent in the nontransplanted CF patients, sensitization to fungi and notably to aspergillus may lead to allergic bronchopulmonary aspergillosis. The latter necessitates treatment with systemic corticosteroids, which may be combined with antifungal agents [25].

Pregnancy. In animal studies, azole antifungals cross the placenta and are teratogenic at high doses (table 2). Craniofacial, skeletal, and cardiac malformations, similar to those observed in animal studies, have been described after first trimester use of prolonged high doses of fluconazole (400-800 mg daily) [26-28]. However, low-dosage regimens have not been associated with an increased birth defect risk in various studies including several thousand first trimester exposures to fluconazole $[29,30]$. Likewise, itraconazole has not been associated with an increased birth defect risk according to prospective studies including several hundred first trimester exposures [31]. Human data are lacking for voriconazole and posaconazole. Based on current data, azole derivatives should be used with caution when administered systemically, at least during the first trimester of pregnancy. Fluconazole and itraconazole are to be preferred as the best investigated drugs.

Amphotericin B crosses the placenta, and the limited human data do not allow for an adequate risk assessment (table 2). The systemic use of amphotericin B should be reserved for life-threatening infections [9]. Liposomal amphotericin B should be preferred to reduce the risk of nephrotoxicity and oral or local use is acceptable during pregnancy as systemic absorption is minimal.

Oral nystatin is poorly absorbed and has not been associated with an increased risk of birth defect [32] (table 2).

Breastfeeding. Fluconazole is transferred into human breast milk, resulting in an RID equivalent to $5 \%$ of the usual pediatric dose $(6 \mathrm{mg} / \mathrm{kg} /$ day $)$ [10,33]. Fluconazole is associated with a good safety profile in pediatric patients. Although data on the systemic use of itraconazole, posaconazole and voriconazole are unavailable $[9,10]$, breastfeeding interruption is not justified, but their use should be reserved for situations requiring a systemic use (table 2). The best-investigated compound fluconazole and nystatin for local infections should be preferred whenever possible. Even if no data are available for am- 
photericin in breastfeeding, its use is probably associated with a limited risk due to its poor oral bioavailability [10].

Antivirals

Respiratory viral infections may lead to prolonged symptoms and may worsen the course of CF. Despite a paucity of studies in this context, it is considered that neuraminidase inhibitors against influenza infection may be helpful in limiting clinical manifestations [34].

Pregnancy. No evidence of embryo- or fetotoxic risks has been reported for oseltamivir in more than several hundred documented exposures [35-39]. Oseltamivir is considered a first choice in influenza treatment during pregnancy [9] (table 2).

Breastfeeding. Oseltamivir is transferred into human milk in limited amounts, with an RID of $<0.5$ [10] (table 2).

\section{Inhaled Corticosteroids}

Pregnancy. Safety of inhaled corticosteroids (ICS) during pregnancy is well-established (e.g. several thousand documented pregnancy exposures for budesonide) and the vast majority of studies did not report any increased risk of birth defects or adverse perinatal outcomes associated with ICS use [40-47]. An increased overall malformation rate in infants exposed to high-dose ICS treatments $(>1,000 \mu \mathrm{g} /$ day of beclomethasone dipropionate-chlorofluorocarbon equivalent) was suggested [48]. However, these studies did not account for the indication as an important confounding factor (e.g. asthma severity) [41] and results have not been confirmed in other large cohort studies or meta-analyses [41, 44, 46, 49, 50]. Data on long-term ICS use during pregnancy and the incidence of pediatric diseases in the exposed offspring are scarce but mostly reassuring [50]. Even though fluticasone and beclomethasone are not as well documented as budesonide, both show a similar safety profile [50]. ICS are considered to be safe during pregnancy and can be continued in CF patients if needed (table 3).

Breastfeeding. A small study of 8 women treated by inhaled budesonide during lactation reported an RID of $<1 \%$ [51]. Exposed infants had undetectable serum budesonide concentrations. There are no available data on the excretion of other ICS into breast milk. Based on these results and on the limited systemic absorption, ICS are considered compatible with breastfeeding (table 3 ).

Inhaled $\beta_{2}$-Agonists

Pregnancy. Inhaled $\beta_{2}$-agonists are divided into shortacting (SABA; e.g. salbutamol/albuterol, terbutaline) and long-acting bronchodilators (LABA, e.g. salmeterol, for- moterol). A few studies found a slightly increased risk of all congenital malformations [52] or specific birth defects such as gastroschisis [53], heart defects [52, 54], cleft lip [55], esophageal atresia [47], anorectal atresia [47], or omphalocele [47] after exposure to a SABA (e.g. salbutamol/ albuterol, terbutaline). However, results from a recent meta-analysis suggest that these associations may be chance findings or related to the underlying asthma severity [41]. In contrast, no increase in malformation rate was reported by large database studies [44, 50, 56, 57]. Several studies support the absence of obstetrical or perinatal complications associated with SABA use [44, 58-60]. There are limited observational data on the safety of LABA during pregnancy, although an increase in cardiac malformations has been reported in one study [56]. No difference in perinatal risks has been reported between salmeterol and formoterol [61]. Even if systemic absorption of inhaled $\beta_{2}$-agonists is generally low, a systemic effect on mother and fetus cannot be formally excluded (e.g. tachycardia, arrhythmia, glucose intolerance, inhibition of uterine contractions). Patients requiring a SABA or LABA to control asthmatic symptoms should be encouraged to continue treatment during pregnancy. The best investigated drugs should be preferred (i.e. salbutamol/albuterol for SABA; salmeterol or formoterol for LABA; table 3).

Breastfeeding. No published data exist on the use of inhaled $\beta_{2}$-agonists during lactation. Based on the limited systemic absorption after administration by inhalation, inhaled $\beta_{2}$-agonists are considered compatible with breastfeeding, and patients should be encouraged to continue inhaled $\beta_{2}$-agonists during breastfeeding (table 3 ).

\section{Inhaled Anticholinergics}

Pregnancy. Inhaled anticholinergics such as ipratropium are not teratogenic in animals, but well-controlled studies in humans are lacking. One case of renal obstruction was observed out of 37 infants born to women who took ipratropium during pregnancy [62]. Even if systemic absorption is limited, inhaled anticholinergics should only be used if first-line therapies are not effective (e.g. SABA, LABA, ICS; table 3).

Breastfeeding. No data on the safety of inhaled anticholinergics in breastfeeding are available, but excreted amounts of drug are likely to be negligible due to limited systemic absorption (table 3 ).

\section{Drugs Improving Airway Clearance}

Pregnancy. No data on mucolytic agents, hypertonic saline (3-7\%), and mannitol use during pregnancy are available, and therefore proper risk assessment is not pos- 
Table 3. Drugs acting on the respiratory system in pregnant and lactating CF patients

\begin{tabular}{|c|c|c|c|c|c|c|}
\hline \multirow[t]{2}{*}{ Drug } & \multicolumn{3}{|l|}{ Pregnancy } & \multicolumn{3}{|l|}{ Lactation } \\
\hline & safety data & compatibility & recommendations & $\begin{array}{l}\text { level of } \\
\text { exposure }\end{array}$ & compatibility & recommendations \\
\hline $\begin{array}{l}\text { Inhaled cortico- } \\
\text { steroids (for } \\
\text { systemic use, see } \\
\text { immuno- } \\
\text { suppressants) }\end{array}$ & $\begin{array}{l}\text { Numerous } \\
\text { human data; } \\
\text { limited } \\
\text { systemic } \\
\text { absorption }\end{array}$ & $\begin{array}{l}\text { Drug of } \\
\text { choice in } \\
\text { pregnant CF } \\
\text { patients }\end{array}$ & $\begin{array}{l}\text { Well-established compounds of } \\
\text { the class should be preferred } \\
\text { (e.g. budesonide, fluticasone, } \\
\text { beclomethasone) }\end{array}$ & $\begin{array}{l}\text { RID }<1 \% \\
\text { for bude- } \\
\text { sonide }\end{array}$ & $\begin{array}{l}\text { Drug of } \\
\text { choice in } \\
\text { lactating CF } \\
\text { patients }\end{array}$ & $\begin{array}{l}\text { Well-established } \\
\text { compounds of the class } \\
\text { should be preferred (e.g. } \\
\text { budesonide) }\end{array}$ \\
\hline $\begin{array}{l}\text { Inhaled } \\
\text { selective } \\
\beta_{2} \text {-agonists }\end{array}$ & $\begin{array}{l}\text { Numerous } \\
\text { human data; } \\
\text { limited } \\
\text { systemic } \\
\text { absorption }\end{array}$ & $\begin{array}{l}\text { Drug of } \\
\text { choice in } \\
\text { pregnant CF } \\
\text { patients }\end{array}$ & $\begin{array}{l}\text { Well-established compounds of } \\
\text { the class should be preferred (i.e. } \\
\text { salbutamol/albuterol for SABA; } \\
\text { salmeterol, formoterol for } \\
\text { LABA) } \\
\text { Despite limited systemic } \\
\text { absorption, a possible systemic } \\
\text { effect cannot be ruled out }\end{array}$ & RID $<1 \%$ & $\begin{array}{l}\text { Drug of } \\
\text { choice in } \\
\text { lactating CF } \\
\text { patients }\end{array}$ & $\begin{array}{l}\text { Well-established } \\
\text { compounds of the class } \\
\text { should be preferred (i.e. } \\
\text { salbutamol/albuterol for } \\
\text { SABA; salmeterol, } \\
\text { formoterol for LABA) }\end{array}$ \\
\hline $\begin{array}{l}\text { Inhaled } \\
\text { anticholinergics }\end{array}$ & $\begin{array}{l}\text { Limited } \\
\text { human data; } \\
\text { limited } \\
\text { systemic } \\
\text { absorption }\end{array}$ & $\begin{array}{l}\text { Second-line } \\
\text { treatment in } \\
\text { pregnant CF } \\
\text { patients }\end{array}$ & $\begin{array}{l}\text { Should be used only if safer } \\
\text { alternatives are not effective }\end{array}$ & $\begin{array}{l}\text { RID } \\
\text { unknown }\end{array}$ & $\begin{array}{l}\text { Second-line } \\
\text { treatment in } \\
\text { lactating CF } \\
\text { patients }\end{array}$ & $\begin{array}{l}\text { Well-established } \\
\text { compounds of the class } \\
\text { should be preferred (e.g. } \\
\text { ipratropium) }\end{array}$ \\
\hline $\begin{array}{l}\text { Leukotriene } \\
\text { antagonists }\end{array}$ & $\begin{array}{l}\text { Limited } \\
\text { human data }\end{array}$ & $\begin{array}{l}\text { Second-line } \\
\text { treatment }\end{array}$ & $\begin{array}{l}\text { Should be used only if safer } \\
\text { alternatives are not effective }\end{array}$ & $\begin{array}{l}\text { RID } \\
\text { unknown }\end{array}$ & $\begin{array}{l}\text { Second-line } \\
\text { treatment in } \\
\text { lactating CF } \\
\text { patients }\end{array}$ & $\begin{array}{l}\text { Should be used only if } \\
\text { safer alternatives are not } \\
\text { effective }\end{array}$ \\
\hline $\begin{array}{l}\text { Drugs } \\
\text { improving } \\
\text { airway clearance }\end{array}$ & $\begin{array}{l}\text { Limited } \\
\text { human data; } \\
\text { important } \\
\text { hindsight }\end{array}$ & $\begin{array}{l}\text { Drug of } \\
\text { choice in } \\
\text { pregnant CF } \\
\text { patients }\end{array}$ & $\begin{array}{l}\text { limited bioavailability for } \\
\text { mucolytic agents, hypertonic } \\
\text { saline }(3-7 \%) \text { and mannitol }\end{array}$ & $\begin{array}{l}\text { RID } \\
\text { unknown }\end{array}$ & $\begin{array}{l}\text { Drug of } \\
\text { choice in } \\
\text { lactating CF } \\
\text { patients }\end{array}$ & $\begin{array}{l}\text { Limited systemic bio- } \\
\text { availability for mucolytic } \\
\text { agents, hypertonic saline } \\
(3-7 \%) \text { and mannitol }\end{array}$ \\
\hline $\begin{array}{l}\text { CFTR } \\
\text { modulators }\end{array}$ & $\begin{array}{l}\text { No human } \\
\text { data }\end{array}$ & $\begin{array}{l}\text { Should be } \\
\text { used with } \\
\text { caution }\end{array}$ & Safety has not been assessed & $\begin{array}{l}\text { RID } \\
\text { unknown }\end{array}$ & $\begin{array}{l}\text { Should be } \\
\text { used with } \\
\text { caution }\end{array}$ & $\begin{array}{l}\text { Safety has not been } \\
\text { assessed }\end{array}$ \\
\hline $\begin{array}{l}\text { Inhaled } \\
\text { rhDNase }\end{array}$ & $\begin{array}{l}\text { Limited } \\
\text { human data; } \\
\text { poor systemic } \\
\text { absorption }\end{array}$ & $\begin{array}{l}\text { Drug of } \\
\text { choice in } \\
\text { pregnant CF } \\
\text { patients }\end{array}$ & $\begin{array}{l}\text { Limited systemic absorption. } \\
\text { Similar to endogenous } \\
\text { compound }\end{array}$ & $\begin{array}{l}\text { RID } \\
\text { unknown }\end{array}$ & $\begin{array}{l}\text { Drug of } \\
\text { choice in } \\
\text { lactating } \mathrm{CF} \\
\text { patients }\end{array}$ & $\begin{array}{l}\text { Limited systemic } \\
\text { absorption }\end{array}$ \\
\hline
\end{tabular}

sible to date. However, as those preparations have a limited systemic absorption when administered by inhalation, no fetal adverse effects are expected (table 3 ).

Clinical experience with dornase alfa, a human recombinant deoxyribonuclease I, is relatively small, and therefore human studies in pregnancy are lacking. Due to the presence of endogenous DNase in human serum and the poor systemic absorption of inhaled dornase alfa, this medication may be used in pregnant CF women if needed (table 3).

Breastfeeding. Excretion of mucolytic agents such as $\mathrm{N}$-acetylcysteine and hypertonic saline into breast milk has not been investigated. Considering their general safety profile and limited absorption after inhalation, the use of these compounds is probably safe for the breastfed infant (table 3).

Studies investigating dornase alfa safety during lactation are lacking. Since it is a large protein poorly absorbed after inhalation, excretion into breast milk should be low and is not expected to cause any adverse effects in breastfed infants (table 3).

\section{Leukotriene Antagonists}

Pregnancy. Leukotriene antagonists have been used in $\mathrm{CF}$ for their anti-inflammatory properties [63]. Limited human data exist on the safety of leukotriene antagonists during pregnancy. According to the manufacturer pregnancy registry including several hundreds of patients, 19 
cases of congenital anomalies were reported until July 2009 with montelukast [62]. Limb reduction defects were present in 6 montelukast-exposed children, but this association was not confirmed in a large database study [64] or in 3 other studies that did not report any increase in perinatal complications or congenital malformations $[65$, 66]. Leukotriene antagonists should be considered as a second-line treatment during pregnancy, and, when needed, the best investigated leukotriene antagonist montelukast should be preferred (table 3 ).

Breastfeeding. No published information is available on the use of leukotriene antagonists during lactation. Data on zafirlukast suggest that only small amounts are excreted into human breast milk (probably RID <1\%) [67]. Due to limited experience, leukotriene antagonists should only be used during breastfeeding when alternative antiasthmatic drugs are not effective (table 3 ).

\section{CF Transmembrane Conductance Regulator}

Modulators

Pregnancy. Drugs modulating CF transmembrane conductance regulator (CFTR) dysfunction have been the focus of research during the recent years. Ivacaftor and combination of ivacaftor/lumacaftor have been licensed, respectively, for patients who have one gating CFTR mutations [68] and patients homozygous for the F508del mutation [69]. Clinical experience with ivacaftor/lumacaftor is relatively small, and human studies investigating drug safety during pregnancy are lacking. Ivacaftor/lumacaftor should be used with caution in pregnant CF patients until more clinical data are available (table 3).

Breastfeeding. Due to the lack of data of ivacaftor and ivacaftor/lumacaftor excretion into breast milk, it should better not be used during breastfeeding (table 3 ).

\section{Gastrointestinal System}

CF digestive system manifestations are diverse and may include pancreatic insufficiency, acute or chronic pancreatitis, liver cirrhosis, chronic constipation, distal intestinal obstruction syndrome, gastroesophageal reflux disease, esophageal dysmotility, and cholestasis [70]. Pancreatic insufficiency predisposes to fat-soluble vitamin deficiency and may lead to additional manifestations, such as decreased bone mineral density due to vitamin $\mathrm{D}$ or $\mathrm{K}$ deficiency. CF-related diabetes occurrence increases with age, affecting almost $50 \%$ of patients after 40 years.

\section{Pancreatic Enzymes}

Pregnancy. No data of pancreatic enzyme use during pregnancy are available, and therefore proper risk assess- ment is not possible to date. As those preparations have a very limited systemic absorption, no fetal adverse effects are expected [9] (table 4).

Breastfeeding. Pancreatic enzymes can be considered compatible with breastfeeding (table 4 ) due to their limited absorption [10, 67].

\section{Antacids}

Pregnancy. Antacids may be used throughout pregnancy. Fixed combinations of aluminum and magnesium salts should be preferred and used at recommended doses. No associations with an increased rate of birth defects have been detected after more than 1,500 exposures during the first trimester with ranitidine $[71,72]$. No associations have been found between proton pump inhibitor use during pregnancy and increased rate of birth defects in studies including several thousands of patients $[73,74]$. Omeprazole, the best investigated proton pump inhibitor to date, and its enantiomer esomeprazole are the medication of choice. Misoprostol has an uterotonic activity and is linked to an increased risk of Moebius sequence. It is contraindicated during pregnancy except for specific obstetrical indications (table 4).

Breastfeeding. Antacids can be used during breastfeeding. Ranitidine reaches variable concentrations in the mother's milk, corresponding however to smaller amounts than the usual pediatric dosage. Omeprazole and esomeprazole are acid labile compounds and are likely to be destroyed in the infant's stomach prior to systemic absorption. Based on these considerations, antacids are not expected to cause adverse effects in breastfed infants (table 4 ).

Prokinetics

Pregnancy. Metoclopramide has been widely used in the treatment of nausea and vomiting in pregnancy, and safety data are numerous for this compound $[75,76]$. It is considered as the antiemetic of choice during pregnancy [9] (table 4). Domperidone is not a drug of choice in pregnancy as its safety has only been demonstrated in a small study.

Breastfeeding. Metoclopramide and domperidone are excreted in small amounts into breast milk [77, 78] with no adverse events reported in breastfed infants. If both prokinetics may be used during breastfeeding, domperidone is excreted in smaller amounts into milk and is less able to cross the infant blood-brain barrier (table 4).

Laxatives

Pregnancy. Bulking agents characterized by a high content of cellulose and derivatives, osmotic laxatives 
Table 4. Drugs acting on the gastrointestinal system in CF pregnant and lactating patients

\begin{tabular}{|c|c|c|c|c|c|c|}
\hline \multirow[t]{2}{*}{ Drug } & \multicolumn{3}{|l|}{ Pregnancy } & \multicolumn{3}{|l|}{ Lactation } \\
\hline & safety data & compatibility & recommendations & level of exposure & compatibility & recommendations \\
\hline $\begin{array}{l}\text { Pancreatic } \\
\text { enzymes }\end{array}$ & $\begin{array}{l}\text { Limited human } \\
\text { data; poor } \\
\text { systemic } \\
\text { absorption }\end{array}$ & $\begin{array}{l}\text { Drug of choice } \\
\text { in pregnant CF } \\
\text { patients }\end{array}$ & & RID unknown & $\begin{array}{l}\text { Drug of choice } \\
\text { in lactating CF } \\
\text { patients }\end{array}$ & $\begin{array}{l}\text { Poor systemic } \\
\text { absorption }\end{array}$ \\
\hline Antacids & $\begin{array}{l}\text { Numerous } \\
\text { human data; } \\
\text { poor systemic } \\
\text { absorption }\end{array}$ & $\begin{array}{l}\text { Drug of choice } \\
\text { in pregnant CF } \\
\text { patients } \\
\text { Misoprostol is } \\
\text { contraindicated } \\
\text { during } \\
\text { pregnancy }\end{array}$ & $\begin{array}{l}\text { Well-established compounds of the } \\
\text { class should be preferred (i.e. } \\
\text { omeprazole or esomeprazole for } \\
\text { proton pump inhibitors, ranitidine } \\
\text { for H2 receptor antagonists) } \\
\text { Misoprostol has abortive properties } \\
\text { and is linked to an increased risk of } \\
\text { Moebius sequence }\end{array}$ & $\begin{array}{l}\text { RID unknown } \\
\text { for magnesium } \\
\text { or aluminum } \\
\text { salts } \\
\text { RID }>5 \% \text { for } \\
\text { H2 blockers } \\
\text { RID }<2 \% \text { for } \\
\text { proton pump } \\
\text { inhibitors }\end{array}$ & $\begin{array}{l}\text { Drug of choice } \\
\text { in lactating CF } \\
\text { patients }\end{array}$ & $\begin{array}{l}\text { The most documented } \\
\text { compounds of the class } \\
\text { should be preferred (i.e. } \\
\text { omeprazole, esomepra- } \\
\text { zole for proton pump } \\
\text { inhibitors, ranitidine for } \\
\text { H2 receptor antago- } \\
\text { nists) }\end{array}$ \\
\hline Prokinetics & $\begin{array}{l}\text { Numerous } \\
\text { human data } \\
\text { for metoclo- } \\
\text { pramide; limited } \\
\text { human data for } \\
\text { domperidone }\end{array}$ & $\begin{array}{l}\text { Drug of choice } \\
\text { in pregnant CF } \\
\text { patients (meto- } \\
\text { clopramide) }\end{array}$ & $\begin{array}{l}\text { Metoclopramide should be preferred } \\
\text { in the first trimester }\end{array}$ & $\begin{array}{l}\text { RID }<2 \% \text { for } \\
\text { domperidone } \\
\text { RID } 5-15 \% \text { for } \\
\text { metoclopramide }\end{array}$ & $\begin{array}{l}\text { Drug of choice } \\
\text { in lactating CF } \\
\text { patients (meto- } \\
\text { clopramide) }\end{array}$ & \\
\hline Laxatives & $\begin{array}{l}\text { Limited human } \\
\text { data; important } \\
\text { hindsight; poor } \\
\text { systemic } \\
\text { absorption }\end{array}$ & $\begin{array}{l}\text { Drug of choice } \\
\text { in pregnant CF } \\
\text { patients }\end{array}$ & $\begin{array}{l}\text { Limited systemic absorption for } \\
\text { most laxatives } \\
\text { Use of anthraquinones should be } \\
\text { limited to short periods in case of } \\
\text { refractory constipation } \\
\text { Long-term use of mineral oil should } \\
\text { be avoided during pregnancy }\end{array}$ & RID unknown & $\begin{array}{l}\text { Drug of choice } \\
\text { in lactating CF } \\
\text { patients }\end{array}$ & $\begin{array}{l}\text { Limited systemic } \\
\text { absorption for most } \\
\text { laxatives } \\
\text { Bulking agents and } \\
\text { osmotic laxatives should } \\
\text { be preferred } \\
\text { Short-time use of senna } \\
\text { preparations (i.e. con- } \\
\text { taining anthraquinones) } \\
\text { and mineral oil is } \\
\text { acceptable }\end{array}$ \\
\hline $\begin{array}{l}\text { Antidia- } \\
\text { betics }\end{array}$ & $\begin{array}{l}\text { Numerous } \\
\text { human data for } \\
\text { insulin; limited } \\
\text { human data for } \\
\text { oral antidiabetics }\end{array}$ & $\begin{array}{l}\text { Drug of choice } \\
\text { in pregnant CF } \\
\text { patients (insulin) }\end{array}$ & $\begin{array}{l}\text { Poor control of blood sugar level } \\
\text { during pregnancy is correlated with } \\
\text { pre- and postnatal developmental } \\
\text { impairment (e.g. increased rate of } \\
\text { congenital malformation, macroso- } \\
\text { mia, neonatal hypoglycemia) } \\
\text { Insulin has no placental transfer and } \\
\text { should be preferred } \\
\text { Metformin can be considered } \\
\text { during the second and third trimesters }\end{array}$ & $\begin{array}{l}\text { RID }<2 \% \text { for } \\
\text { metformin }\end{array}$ & $\begin{array}{l}\text { Drug of choice } \\
\text { in pregnant CF } \\
\text { patients } \\
\text { (insulin) }\end{array}$ & $\begin{array}{l}\text { Insulin and metformin } \\
\text { should be preferred }\end{array}$ \\
\hline $\begin{array}{l}\text { Ursodeoxy- } \\
\text { cholic acid }\end{array}$ & $\begin{array}{l}\text { Limited human } \\
\text { data }\end{array}$ & $\begin{array}{l}\text { To be used with } \\
\text { caution }\end{array}$ & Avoid during the first trimester & RID unknown & $\begin{array}{l}\text { Drug of choice } \\
\text { in lactating CF } \\
\text { patients }\end{array}$ & $\begin{array}{l}\text { Only trace amounts in } \\
\text { the maternal plasma }\end{array}$ \\
\hline $\begin{array}{l}\text { Bisphos- } \\
\text { phonates }\end{array}$ & $\begin{array}{l}\text { Limited human } \\
\text { data }\end{array}$ & $\begin{array}{l}\text { To be used with } \\
\text { caution }\end{array}$ & Avoid in pregnancy & RID unknown & $\begin{array}{l}\text { To be used } \\
\text { with caution }\end{array}$ & $\begin{array}{l}\text { Avoid during breastfee- } \\
\text { ding even if adverse } \\
\text { effect is not expected } \\
\text { If used, no breastfeeding } \\
\text { during the peak plasma } \\
\text { time (e.g. } 2 \text { h for } \\
\text { alendronate) }\end{array}$ \\
\hline Vitamins & $\begin{array}{l}\text { Important } \\
\text { hindsight }\end{array}$ & $\begin{array}{l}\text { Drug of choice } \\
\text { in pregnant CF } \\
\text { patients }\end{array}$ & $\begin{array}{l}\text { Except for vitamin A, vitamin } \\
\text { deficiency should be compensated } \\
\text { according to laboratory normal } \\
\text { values } \\
\text { For vitamin A, doses } \leq 10,000 \\
\text { IU are considered safe }\end{array}$ & $\begin{array}{l}\text { Important } \\
\text { hindsight }\end{array}$ & $\begin{array}{l}\text { Drug of choice } \\
\text { in pregnant CF } \\
\text { patients }\end{array}$ & $\begin{array}{l}\text { Any vitamin deficiency } \\
\text { should be addressed }\end{array}$ \\
\hline
\end{tabular}

Safety of Drugs during Pregnancy and Breastfeeding in CF Patients 
such as lactulose, lactitol, macrogol (without electrolytes), and glycerol used rectally are nonabsorbable laxatives. These are considered to be safe during pregnancy and should be used as first-line agents. A stimulation effect in the uterine musculature and an in utero meconium release cannot be ruled out with anthraquinonebased preparations (e.g. senna). Chronic use of mineral oil may interfere with the absorption of fat-soluble vitamins and be the cause of lipoid pneumonia after aspiration. Therefore, the use of anthraquinone-based preparations and mineral oil should be limited to short periods in case of refractory constipation (table 4). There is no human data regarding the reproductive safety of prucalopride, which does not allow a proper risk assessment. Thus, this drug should be avoided during the first trimester of pregnancy.

Breastfeeding. The use of bulking agents and osmotic laxatives is probably safe for the breastfed infant owing to their nonabsorbable properties [9]. A risk of diarrhea in the breastfed infant cannot be excluded with anthraquinone-based preparations (table 4). There are no human data regarding the safety of prucalopride, and this drug should thus be avoided during breastfeeding.

\section{Ursodeoxycholic Acid (Ursodiol)}

Pregnancy. Ursodeoxycholic acid improves bile flow and is used in patients presenting CF-related liver disease. It is also used in the management of gestational cholestasis in the second and third trimester in non-CF patients. No malformations have been reported, but the scarce data do not allow a proper risk assessment. Thus, this drug should be avoided during the first trimester of pregnancy (table 4). [79].

Breastfeeding. Ursodeoxycholic acid is not excreted in significant amounts into milk $[80,81]$. When indicated, its use is acceptable during breastfeeding (table 4).

\section{Bisphosphonate}

Pregnancy. No malformations have been reported after exposure to bisphosphonate in humans, the scarce data available do not allow a proper risk assessment though. Thus, this drug class should be avoided during pregnancy (table 4).

Breastfeeding. Based on their limited systemic absorption, the use of these compounds is probably safe for the breastfed infant [9]. If a bisphosphonate is used during breastfeeding, the infant should not be breastfed during the peak plasma time (e.g. $2 \mathrm{~h}$ for alendronate).

\section{Antidiabetics}

Pregnancy. Poor control of blood sugar level during pregnancy is correlated with adverse pregnancy (e.g. increased rate of congenital malformation and miscarriage, macrosomia, hydramnios, traumatic birth) and neonatal outcomes (e.g. neonatal hypoglycemia, brachial plexus injury) [82]. Therefore, maintaining euglycemia throughout pregnancy is essential. Insulin has no placental transfer and is considered first-line treatment in diabetes during pregnancy. Human data are limited regarding the reproductive safety of oral antidiabetics. Recent studies investigating metformin safety did not show an increased rate of birth defects, when used to treat insulin resistance in women with polycystic ovarian syndrome [83]. However, available data do not allow an accurate risk assessment, and larger studies are warranted in order to confirm safety and efficacy of this drug during the first trimester. If insulin cannot be used, metformin is a possible alternative during the second and third trimesters (table 4).

Breastfeeding. Insulin is a large peptide that is not excreted in significant amounts into breast milk and has very poor systemic absorption after milk ingestion [84]. New insulin analogues also seem to be safe during lactation. Only small amounts of metformin are found in the mother's milk and no adverse events have been reported in breastfed infants $[85,86]$. Insulin and metformin are considered as safe during breastfeeding (table 4).

\section{Vitamins}

Pregnancy. Approximately 85\% of CF patients present exocrine pancreatic insufficiency, which predisposes to an impaired absorption of fat-soluble vitamins. Adequate nutritional status has to be maintained throughout pregnancy (table 4). Serum levels of vitamins that are at high risk of deficiency [i.e. fat-soluble vitamins (A, D, E, K) and vitamin $\mathrm{B}_{12}$ ] should be closely monitored. A teratogenic effect similar to retinoids has been associated with high doses of vitamin A (>25,000 UI). This risk has not been confirmed in a large cohort study evaluating the risk of high doses of vitamin A. A daily dose of $<10,000 \mathrm{UI}$ is considered safe [87]. Supplementation with folic acid (0.4-0.8 mg daily) should be started in women planning pregnancy and continued throughout the first trimester for the prevention of neural tube defects [88].

Breastfeeding. Adequate nutritional status has to be maintained in CF patients throughout lactation (table 4). Serum levels of vitamins that are at high risk of deficiency [i.e. fat-soluble vitamins $A, D, E, K$ ) and vitamin $B_{12}$ ] should be closely monitored. 
cocorticoids during the second and third trimesters, an increased risk of intrauterine growth retardation, premature birth, transient hypoglycemia, hypotension, and electrolyte disturbances in the newborn has been observed.

CF patients receive long-term immunosuppressive regimens after lung transplantation. Medication commonly used in this context includes cyclosporine, mycophenolate, tacrolimus and corticosteroids. Cyclosporine is one of the best-studied immunosuppressants during pregnancy. While tacrolimus is also compatible with pregnancy, mycophenolate should be avoided (table 5). Cyclosporine and tacrolimus cross the placenta, and fetal levels reach 30-64 and 23\% of maternal plasma concentration, respectively [102-105]. Data on a large number of pregnancies exposed to cyclosporine have not shown a significant increase in major birth defect risk [106-108]. There are less data available on tacrolimus use during pregnancy; however, more than 200 pregnancies have been documented, indicating no teratogenic risk [109113]. An increased risk of fetal growth restriction, preterm delivery, and preeclampsia has been observed in pregnancies exposed to cyclosporine and tacrolimus $[108,113,114]$. However, underlying medical condition and concomitant drug exposure may also have played a role in this outcome. One study observed a difference in the development or maturation of several cellular components of the immune system in children exposed to cyclosporine during pregnancy compared to nonexposed controls, although no signs of immunodeficiency were evident [115]. Other studies did not show a significant immunosuppressive effect of cyclosporine and other immunosuppressants in children exposed during pregnancy $[116,117]$. Decreased kidney function and hyperkalemia have been observed in neonates exposed to tacrolimus throughout pregnancy $[113,118]$. Two studies on long-term effects of in utero exposure to cyclosporine did not reveal any anomalies in renal function or cognitive and neurobehavioral development $[119,120]$.

Mycophenolate use during pregnancy is associated with increased miscarriage and major birth defect risks (table 5). The characteristic mycophenolate embryopathy consists of malformations of the ear (i.e. microtia, atresia of the external ear), craniofacial malformations (i.e. cleft lip and/or palate, micrognathia), ocular malformations (i.e. hypertelorism, coloboma), and defects of the distal limbs, heart, esophagus, and kidney [121-123]. One prospective study observed an increased risk for major birth defects of $26 \%$ after first-trimester exposure to mycophenolate [123]. A transplantation pregnancy registry reported a major birth defect rate of $23 \%$ [124].

\section{Breastfeeding}

NSAIDs are excreted in low amounts into breast milk. Ibuprofen is the drug of first choice, because of the short half-life and the minimal transfer to breast milk [125].

Prednisone and prednisolone are the corticoids of choice for systemic use in breastfeeding mothers. Published data indicate that a maternal dose of up to $20 \mathrm{mg} /$ day results in low milk levels (RID $<2 \%)[126,127]$. At higher doses $(80 \mathrm{mg} /$ day $)$, the infant would ingest less than $10 \%$ of the endogenous cortisol production [126]. No adverse events have been observed in breastfed infants.

Even though in 2001 some authors have advised against cyclosporine use during breastfeeding [128], more recent data indicate that this drug is compatible with breastfeeding if the child can be adequately monitored (table 5). Cyclosporine is excreted into breast milk in variable amounts, but data on approximately 20 mother-child pairs have shown that RID is about 2\% [129]. In most infants, cyclosporine plasma concentrations were below the detection limit. However, isolated case reports showed detectable blood levels, despite relatively low milk concentrations $[130,131]$. No clinical adverse effects have been reported in breastfed infants. Tacrolimus treatment is compatible with breastfeeding under clinical monitoring of the infant. Tacrolimus excretion into breast milk is low (RID $\leq 0.5 \%)[132,133]$. Infant plasma concentrations are usually undetectable, and no adverse effects in breastfed infants have been reported. Since there is no information available on mycophenolate use during breastfeeding, this drug should be avoided.

\section{Vaccines}

Pregnancy

There is no evidence that live or inactivated vaccines have embryo- or fetotoxic effects (table 6). Live vaccines have a theoretical risk of fetal infection and should therefore be avoided during pregnancy (i.e. measles, mumps, rubella, varicella, yellow fever) [9]. Routine vaccination should be updated before pregnancy and vaccination during pregnancy may be performed in case of obvious risk of infection to protect mother and child [9]. Maternal immunization is increasingly considered as a way to protect young infants against infection. As an example, the Center for Disease Control and Prevention (CDC) recommends routine influenza vaccination even during the first trimester [134]. CDC also recommends that women receive the pertussis vaccine during the third trimester of each pregnancy to provide early life protection to the newborn [135]. 
Table 6. Vaccines in pregnant and lactating CF patients

\begin{tabular}{|c|c|c|c|c|c|c|}
\hline \multirow[t]{2}{*}{ Drug } & \multicolumn{3}{|l|}{ Pregnancy } & \multicolumn{3}{|l|}{ Lactation } \\
\hline & safety data & compatibility & recommendations & $\begin{array}{l}\text { level of } \\
\text { exposure }\end{array}$ & compatibility & recommendations \\
\hline $\begin{array}{l}\text { Inactivated } \\
\text { vaccines }\end{array}$ & $\begin{array}{l}\text { Numerous } \\
\text { human data }\end{array}$ & $\begin{array}{l}\text { Drug of choice } \\
\text { in pregnant CF } \\
\text { patients }\end{array}$ & $\begin{array}{l}\text { Before pregnancy, update routine } \\
\text { adult vaccines. During flu season, } \\
\text { pregnant women should be } \\
\text { immunized against influenza, even } \\
\text { during the first trimester }\end{array}$ & n.a. & $\begin{array}{l}\text { Drug of choice } \\
\text { in lactating CF } \\
\text { patients }\end{array}$ & $\begin{array}{l}\text { Breastfeeding women may be } \\
\text { immunized with inactivated vaccines } \\
\text { using standard recommended doses for } \\
\text { adults }\end{array}$ \\
\hline $\begin{array}{l}\text { Live } \\
\text { attenuated } \\
\text { vaccines }\end{array}$ & $\begin{array}{l}\text { Limited } \\
\text { human data }\end{array}$ & $\begin{array}{l}\text { To be used with } \\
\text { caution }\end{array}$ & $\begin{array}{l}\text { Theoretical concern about fetal } \\
\text { infection }\end{array}$ & n.a. & $\begin{array}{l}\text { Drug of choice } \\
\text { in lactating CF } \\
\text { patients }\end{array}$ & $\begin{array}{l}\text { Breastfeeding women may be } \\
\text { immunized with live attenuated } \\
\text { vaccines using standard recommended } \\
\text { doses for adults }\end{array}$ \\
\hline
\end{tabular}

n.a. = Not applicable

Breastfeeding

Breastfeeding women can be immunized with live or inactivated vaccines using standard recommended doses for adults (table 6). All vaccines are considered safe during breastfeeding, with the exception of smallpox vaccine that should not be administered to nursing women and yellow fever vaccine that should only be administered to nursing mothers travelling to high-risk yellow fever-endemic areas [136].

\section{Conclusion}

As most of the drugs representing CF treatment lines cross the placenta or are excreted into human milk, they can potentially affect the fetal development or the breastfed infant. Research addressing the risks and benefits of drugs used in CF patients during pregnancy and lactation is often incomplete or challenged by limited methodology, which often leads to conflicting or inconclusive results (e.g. results uncontrolled for some important confounding factors, limited sample size). Nevertheless, except for mycophenolate and misoprostol, none of the drugs in CF therapeutic arsenal are known to be major teratogens. Several drugs have limited systemic absorption and, therefore, even if the available safety data are scarce, no adverse effects are expected in utero or via breast milk (e.g. inhaled use of colistin, topical or oral nystatin, digestive enzymes, most laxatives). However, some drugs should be used with caution because of small teratogenic or fetotoxic risks (e.g. tetracyclines after 15th week of gestation, sulfonamides during the first trimester and near to delivery, NSAIDs during the second and third trimesters). Others should not

be considered as drugs of first choice in pregnant or lactating $\mathrm{CF}$ patients as they are associated with theoretical risks (e.g. systemic use of aminoglycosides; quinolones; live attenuated vaccines) or data are currently inconclusive (e.g. fluconazole, systemic glucocorticoids, vitamin A $>10,000$ UI). Finally, limited available safety data in humans render the risk assessment difficult for some drugs (e.g. intravenous colistin, intravenous amphotericin B, CFTR modulators, ursodeoxycholic acid, bisphosphonates). Yet, potential treatment benefits for CF patients most often outbalance consequences of maternal health deterioration and potential risks for the unborn child.

\section{Acknowledgements}

The contribution of Etienne Weisskopf and Alice Panchaud to this work was partly supported by grants of the Swiss National Science Foundation (SNSF 320030-135650; SNSF P3SMP3-158808/1).

References
1 Ahmad A, Ahmed A, Patrizio P: Cystic fibrosis and fertility. Curr Opin Obstet Gynecol 2013;25:167-172.

2 Cystic Fibrosis Foundation: Patient Registry annual data report. Bethesda, Cystic Fibrosis Foundation, 2012.

- 3 Schechter MS, Quittner AL, Konstan MW, Millar SJ, Pasta DJ, McMullen A, et al: Longterm effects of pregnancy and motherhood on disease outcomes of women with cystic fibrosis. Ann Am Thorac Soc 2013;10:213-219.

$\checkmark 4$ Ciavattini A, Ciattaglia F, Cecchi S, Gagliardini R, Tranquilli AL: Two successful pregnancies in a woman affected by cystic fibrosis: case report and review of the literature. J Matern Fetal Neonatal Med 2012;25:113-115. 
5 Lau EM, Barnes DJ, Moriarty C, Ogle R, Dentice R, Civitico J, et al: Pregnancy outcomes in the current era of cystic fibrosis care: a 15-year experience. Aust NZ J Obstet Gynaecol 2011; 51:220-224.

6 Lau EM, Moriarty C, Ogle R, Bye PT: Pregnancy and cystic fibrosis. Paediatr Respir Rev 2010;11:90-94.

7 Patel EM, Swamy GK, Heine RP, Kuller JA, James AH, Grotegut CA: Medical and obstetric complications among pregnant women with cystic fibrosis. Am J Obstet Gynecol 2015;212:98.e1-9.

8 Hurt K, Bilton D: Inhaled interventions in cystic fibrosis: mucoactive and antibiotic therapies. Respiration 2014;88:441-448.

9 Schaefer C, Peters P, Miller RK: Drugs during Pregnancy and Lactation: Treatment Options and Risk Assessment, ed 3. Amsterdam, Elsevier, 2014

10 Hale TW, Rowe HE: Medications and Mother's Milk. London, Hale, 2014.

-11 Main E, Grillo L, Rand S: Airway clearance strategies in cystic fibrosis and non-cystic fibrosis bronchiectasis. Semin Respir Crit Care Med 2015;36:251-266.

-12 Tay GT, Reid DW, Bell SC: Inhaled antibiotics in cystic fibrosis (CF) and non-CF bronchiectasis. Semin Respir Crit Care Med 2015 36:267-286.

13 Southern KW, Barker PM, Solis-Moya A, Patel L: Macrolide antibiotics for cystic fibrosis. Cochrane Database Syst Rev 2012;11: CD002203.

14 Pacifici GM: Placental transfer of antibiotics administered to the mother: a review. Int J Clin Pharmacol Ther 2006;44:57-63.

15 Lamont HF, Blogg HJ, Lamont RF: Safety of antimicrobial treatment during pregnancy: a current review of resistance, immunomodulation and teratogenicity. Expert Opin Drug Saf 2014;13:1569-1581.

16 Mylonas I: Antibiotic chemotherapy during pregnancy and lactation period: aspects for consideration. Arch Gynecol Obstet 2011; 283:7-18.

17 Ferreira E, Martin B, Morin C: Grossesse et allaitement: Guide thérapeutique, ed 2. Montréal, Éditions du CHU Sainte-Justine, 2014.

-18 Cooper WO, Hernandez-Diaz S, Arbogast PG, Dudley JA, Dyer SM, Gideon PS, et al: Antibiotics potentially used in response to bioterrorism and the risk of major congenital malformations. Paediatr Perinat Epidemiol 2009;23:18-28.

19 Kirkwood A, Harris C, Timar N, Koren G: Is gentamicin ototoxic to the fetus? J Obstet Gynaecol Can 2007;29:140-145.

-20 Panchaud A, Weisskopf E, Winterfeld U, Baud D, Guidi M, Eap CB, et al: Pharmacokinetic alterations in pregnancy and use of therapeutic drug monitoring (in French). Therapie 2014;69:223-234

-21 Bar-Oz B, Moretti ME, Boskovic R, O’Brien L, Koren G: The safety of quinolones - a metaanalysis of pregnancy outcomes. Eur J Obstet Gynecol Reprod Biol 2009;143:75-78.
22 Berkovitch M, Pastuszak A, Gazarian M, Lewis $\mathrm{M}$, Koren G: Safety of the new quinolones in pregnancy. Obstet Gynecol 1994;84:535-538.

23 Ito S, Blajchman A, Stephenson M, Eliopoulos C, Koren G: Prospective follow-up of adverse reactions in breast-fed infants exposed to maternal medication. Am J Obstet Gynecol 1993; 168:1393-1399.

24 Swissmedicinfo. Information sur le médicament 2015. http://www.swissmedicinfo.ch/ (accessed March 16, 2015).

25 Moss RB: Fungi in cystic fibrosis and noncystic fibrosis bronchiectasis. Semin Respir Crit Care Med 2015;36:207-216.

26 Pursley TJ, Blomquist IK, Abraham J, Andersen HF, Bartley JA: Fluconazole-induced congenital anomalies in three infants. Clin Infect Dis 1996;22:336-340.

27 Lopez-Rangel E, Van Allen MI: Prenatal exposure to fluconazole: an identifiable dysmorphic phenotype. Birth Defects Res A Clin Mol Teratol 2005;73:919-923.

28 Aleck KA, Bartley DL: Multiple malformation syndrome following fluconazole use in pregnancy: report of an additional patient. Am J Med Genet 1997;72:253-256.

29 Norgaard M, Pedersen L, Gislum M, Erichsen $\mathrm{R}$, Sogaard KK, Schonheyder HC, et al: Maternal use of fluconazole and risk of congenital malformations: a Danish population-based cohort study. J Antimicrob Chemother 2008; 62:172-176.

30 Molgaard-Nielsen D, Pasternak B, Hviid A: Use of oral fluconazole during pregnancy and the risk of birth defects. N Engl J Med 2013; 369:830-839.

-31 Pilmis B, Jullien V, Sobel J, Lecuit M, Lortholary $\mathrm{O}$, Charlier $\mathrm{C}$ : Antifungal drugs during pregnancy: an updated review. J Antimicrob Chemother 2015;70:14-22.

\$2 King CT, Rogers PD, Cleary JD, Chapman SW: Antifungal therapy during pregnancy. Clin Infect Dis 1998;27:1151-1160.

33 Force RW: Fluconazole concentrations in breast milk. Pediatr Infect Dis J 1995; 14:235-236.

34 Jagannath VA, Asokan GV, Fedorowicz Z, Lee TW: Neuraminidase inhibitors for the treatment of influenza infection in people with cystic fibrosis. Cochrane Database Syst Rev 2014;2:CD008139.

-35 Beau AB, Hurault-Delarue C, Vial T, Montastruc JL, Damase-Michel C, Lacroix I: Safety of oseltamivir during pregnancy: a comparative study using the EFEMERIS database. BJOG 2014;121:895-900.

36 Saito S, Minakami H, Nakai A, Unno N, Kubo T, Yoshimura Y: Outcomes of infants exposed to oseltamivir or zanamivir in utero during pandemic (H1N1) 2009. Am J Obstet Gynecol 2013;209:130.e1-e9.

37 Xie HY, Yasseen AS 3rd, Xie RH, Fell DB, Sprague AE, Liu N, et al: Infant outcomes among pregnant women who used oseltamivir for treatment of influenza during the H1N1 epidemic. Am J Obstet Gynecol 2013;208:293 e1-e7.

38 Stone KM, Reiff-Eldridge R, White AD, Cordero JF, Brown Z, Alexander ER, et al: Preg- nancy outcomes following systemic prenatal acyclovir exposure: conclusions from the international acyclovir pregnancy registry, 1984-1999. Birth Defects Res A Clin Mol Teratol 2004;70:201-207.

39 Pasternak B, Hviid A: Use of acyclovir, valacyclovir, and famciclovir in the first trimester of pregnancy and the risk of birth defects. JAMA 2010;304:859-866.

40 Martel MJ, Rey E, Beauchesne MF, Perreault S, Lefebvre G, Forget A, et al: Use of inhaled corticosteroids during pregnancy and risk of pregnancy induced hypertension: nested case-control study. BMJ 2005;330:230.

41 Murphy VE, Wang G, Namazy JA, Powell H, Gibson PG, Chambers C, et al: The risk of congenital malformations, perinatal mortality and neonatal hospitalisation among pregnant women with asthma: a systematic review and meta-analysis. BJOG 2013;120:812-822.

42 Norjavaara E, de Verdier MG: Normal pregnancy outcomes in a population-based study including 2,968 pregnant women exposed to budesonide. J Allergy Clin Immunol 2003; 111:736-742.

43 Bracken MB, Triche EW, Belanger K, Saftlas A, Beckett WS, Leaderer BP: Asthma symptoms, severity, and drug therapy: a prospective study of effects on 2,205 pregnancies. Obstet Gynecol 2003;102:739-752.

44 Schatz M, Dombrowski MP, Wise R, Momirova V, Landon M, Mabie W, et al: The relationship of asthma medication use to perinatal outcomes. J Allergy Clin Immunol 2004; 113:1040-1045.

45 Cossette B, Forget A, Beauchesne MF, Rey E Lemiere C, Larivee $P$, et al: Impact of maternal use of asthma-controller therapy on perinatal outcomes. Thorax 2013;68:724-730.

46 Rahimi R, Nikfar S, Abdollahi M: Meta-analysis finds use of inhaled corticosteroids during pregnancy safe: a systematic meta-analysis review. Hum Exp Toxicol 2006;25:447-452.

-47 Lin S, Munsie JP, Herdt-Losavio ML, Druschel CM, Campbell K, Browne ML, et al: Maternal asthma medication use and the risk of selected birth defects. Pediatrics 2012;129: 317-e324.

48 Blais L, Beauchesne MF, Lemiere C, Elftouh $\mathrm{N}$ : High doses of inhaled corticosteroids during the first trimester of pregnancy and congenital malformations. J Allergy Clin Immunol 2009;124:1229-1234.e4.

49 Blais L, Beauchesne MF, Rey E, Malo JL, Forget A: Use of inhaled corticosteroids during the first trimester of pregnancy and the risk of congenital malformations among women with asthma. Thorax 2007;62:320-328.

50 Vasilakis-Scaramozza C, Aschengrau A, Cabral HJ, Jick SS: Asthma drugs and the risk of congenital anomalies. Pharmacotherapy 2013;33:363-368.

51 Falt A, Bengtsson T, Kennedy BM, Gyllenberg A, Lindberg B, Thorsson L, et al: Exposure of infants to budesonide through breast milk of asthmatic mothers. J Allergy Clin Immunol 2007;120:798-802. 
52 Kallen B, Otterblad Olausson P: Use of antiasthmatic drugs during pregnancy. 3. Congenital malformations in the infants. Eur J Clin Pharmacol 2007;63:383-388.

53 Lin S, Munsie JP, Herdt-Losavio ML, Bell E, Druschel C, Romitti PA, et al: Maternal asthma medication use and the risk of gastroschisis. Am J Epidemiol 2008;168:73-79.

- 54 Lin S, Herdt-Losavio M, Gensburg L, Marshall E, Druschel C: Maternal asthma, asthma medication use, and the risk of congenital heart defects. Birth Defects Res A Clin Mol Teratol 2009;85:161-168.

-55 Munsie JW, Lin S, Browne ML, Campbell KA, Caton AR, Bell EM, et al: Maternal bronchodilator use and the risk of orofacial clefts. Hum Reprod 2011;26:3147-3154.

56 Eltonsy S, Forget A, Blais L: Beta2-agonists use during pregnancy and the risk of congenital malformations. Birth Defects Res A Clin Mol Teratol 2011;91:937-947.

-57 Schatz M, Zeiger RS, Harden K, Hoffman CC, Chilingar L, Petitti D: The safety of asthma and allergy medications during pregnancy. J Allergy Clin Immunol 1997;100:301-306.

-58 Martel MJ, Rey E, Beauchesne MF, Perreault S, Forget A, Maghni K, et al: Use of short-acting beta2-agonists during pregnancy and the risk of pregnancy-induced hypertension. J Allergy Clin Immunol 2007;119:576-582.

-59 Wang G, Murphy VE, Namazy J, Powell H, Schatz M, Chambers C, et al: The risk of maternal and placental complications in pregnant women with asthma: a systematic review and meta-analysis. J Matern Fetal Neonatal Med 2014;27:934-942.

60 Bakhireva LN, Jones KL, Schatz M, Johnson D, Chambers CD; Organization of Teratology Information Services Research Group: Asthma medication use in pregnancy and fetal growth. J Allergy Clin Immunol 2005;116: 503-509.

-61 Cossette B, Beauchesne MF, Forget A, Lemiere C, Larivee P, Rey E, et al: Relative perinatal safety of salmeterol vs formoterol and fluticasone vs budesonide use during pregnancy. Ann Allergy Asthma Immunol 2014; 112:459-464.

62 Briggs GG, Freeman RK, Yaffe SJ: Drugs in Pregnancy and Lactation: A Reference Guide to Fetal and Neonatal Risk, ed 9. Philadelphia, Lippincott Williams \& Wilkins, 2011.

63 Schmitt-Grohe S, Eickmeier O, Naujoks C, Schubert R, Lentze MJ, Zielen S, et al: Effects of long-term treatment with montelukast in mild cystic fibrosis (long term treatment with montelukast in cystic fibrosis). Respir Med 2007;101:684.

-64 Nelsen LM, Shields KE, Cunningham ML, Stoler JM, Bamshad MJ, Eng PM, et al: Congenital malformations among infants born to women receiving montelukast, inhaled corticosteroids, and other asthma medications. J Allergy Clin Immunol 2012;129:251-254 e1e6.

-65 Sarkar M, Koren G, Kalra S, Ying A, Smorlesi C, De Santis M, et al: Montelukast use during pregnancy: a multicentre, prospective, comparative study of infant outcomes. Eur J Clin Pharmacol 2009;65:1259-1264.

66 Bakhireva LN, Jones KL, Schatz M, KlonoffCohen HS, Johnson D, Slymen DJ, et al: Safety of leukotriene receptor antagonists in pregnancy. J Allergy Clin Immunol 2007;119:618625.

67 National Institutes of Health: Drugs and Lactation Database (Lactmed). Bethesda, National Institutes of Health.

68 Derichs N: Targeting a genetic defect: cystic fibrosis transmembrane conductance regulator modulators in cystic fibrosis. Eur Respir Rev 2013;22:58-65.

-69 Wainwright CE, Elborn JS, Ramsey BW, Marigowda G, Huang X, Cipolli M, et al: Lumacaftor-ivacaftor in patients with cystic fibrosis homozygous for Phe508del CFTR. N Engl J Med 2015;373:220-231.

70 Kelly T, Buxbaum J: Gastrointestinal manifestations of cystic fibrosis. Dig Dis Sci 2015;60: 1903-1913.

71 Matok I, Gorodischer R, Koren G, Sheiner E, Wiznitzer A, Uziel E, et al: The safety of $\mathrm{H}(2)$ blockers use during pregnancy. J Clin Pharmacol 2010;50:81-87.

72 Gill SK, O'Brien L, Koren G: The safety of histamine 2 (H2) blockers in pregnancy: a metaanalysis. Dig Dis Sci 2009;54:1835-1838.

73 Pasternak B, Hviid A: Use of proton-pump inhibitors in early pregnancy and the risk of birth defects. N Engl J Med 2010;363:21142123.

-74 Gill SK, O’Brien L, Einarson TR, Koren G: The safety of proton pump inhibitors (PPIs) in pregnancy: a meta-analysis. Am J Gastroenterol 2009;104:1541-1545; quiz 0, 6 .

75 Anderka M, Mitchell AA, Louik C, Werler MM, Hernandez-Diaz S, Rasmussen SA, et al: Medications used to treat nausea and vomiting of pregnancy and the risk of selected birth defects. Birth Defects Res A Clin Mol Teratol 2012;94:22-30.

76 Matok I, Gorodischer R, Koren G, Sheiner E, Wiznitzer A, Levy A: The safety of metoclopramide use in the first trimester of pregnancy. N Engl J Med 2009;360:2528-2535.

77 Knoppert DC, Page A, Warren J, Seabrook JA, Carr M, Angelini M, et al: The effect of two different domperidone doses on maternal milk production. J Hum Lact 2013;29:38-44.

78 Kauppila A, Arvela P, Koivisto M, Kivinen S, Ylikorkala O, Pelkonen O: Metoclopramide and breast feeding: transfer into milk and the newborn. Eur J Clin Pharmacol 1983;25:819823.

79 Kondrackiene J, Beuers U, Kupcinskas L: Efficacy and safety of ursodeoxycholic acid versus cholestyramine in intrahepatic cholestasis of pregnancy. Gastroenterology 2005;129: 894-901.

80 Brites D, Rodrigues CM: Elevated levels of bile acids in colostrum of patients with cholestasis of pregnancy are decreased following ursodeoxycholic acid therapy. J Hepatol 1998; 29:743-751.
81 Vitek L, Zelenkova M, Bruha R: Safe use of ursodeoxycholic acid in a breast-feeding patient with primary biliary cirrhosis. Dig Liver Dis 2010;42:911-912.

82 Reece EA: Diabetes-induced birth defects: what do we know? What can we do? Curr Diabet Rep 2012;12:24-32.

83 Gilbert C, Valois M, Koren G: Pregnancy outcome after first-trimester exposure to metformin: a meta-analysis. Fertil Steril 2006;86: 658-663.

84 Whitmore TJ, Trengove NJ, Graham DF, Hartmann PE: Analysis of insulin in human breast milk in mothers with type 1 and type 2 diabetes mellitus. Int J Endocrinol 2012;2012: 296368.

85 Briggs GG, Ambrose PJ, Nageotte MP, Padilla G, Wan S: Excretion of metformin into breast milk and the effect on nursing infants. Obstet Gynecol 2005;105:1437-1441.

86 Gardiner SJ, Kirkpatrick CM, Begg EJ, Zhang M, Moore MP, Saville DJ: Transfer of metformin into human milk. Clin Pharmacol Ther 2003;73:71-77.

87 Mastroiacovo P, Mazzone T, Addis A, Elephant E, Carlier P, Vial T, et al: High vitamin A intake in early pregnancy and major malformations: a multicenter prospective controlled study. Teratology 1999;59:7-11.

88 Center for Disease Control and Prevention: Folic Acid Recommendations 2015. http:// www.cdc.gov/ncbddd/folicacid/recommendations.html (accessed March 13, 2015).

89 Lands LC, Stanojevic S: Oral non-steroidal anti-inflammatory drug therapy for lung disease in cystic fibrosis. Cochrane Database Syst Rev 2013;6:CD001505.

90 Mac Bird T, Robbins JM, Druschel C, Cleves MA, Yang S, Hobbs CA, et al: Demographic and environmental risk factors for gastroschisis and omphalocele in the National Birth Defects Prevention Study. J Pediatr Surg 2009; 44:1546-1551.

91 Torfs CP, Katz EA, Bateson TF, Lam PK, Curry CJ: Maternal medications and environmental exposures as risk factors for gastroschisis. Teratology 1996;54:84-92.

-92 Nezvalova-Henriksen K, Spigset O, Nordeng $\mathrm{H}$ : Effects of ibuprofen, diclofenac, naproxen, and piroxicam on the course of pregnancy and pregnancy outcome: a prospective cohort study. BJOG 2013;120:948-959.

93 Daniel S, Matok I, Gorodischer R, Koren G, Uziel E, Wiznitzer A, et al: Major malformations following exposure to nonsteroidal antiinflammatory drugs during the first trimester of pregnancy. J Rheumatol 2012;39:21632169.

94 Kallen BA, Otterblad Olausson P: Maternal drug use in early pregnancy and infant cardiovascular defect. Reprod Toxicol 2003;17:255-261.

95 Nielsen GL, Sorensen HT, Larsen H, Pedersen L: Risk of adverse birth outcome and miscarriage in pregnant users of non-steroidal antiinflammatory drugs: population based observational study and case-control study. BMJ 2001;322:266-270.
Safety of Drugs during Pregnancy and Breastfeeding in CF Patients
Respiration 2016;91:333-348 DOI: $10.1159 / 000444088$ 
96 Daniel S, Koren G, Lunenfeld E, Bilenko N, Ratzon R, Levy A: Fetal exposure to nonsteroidal anti-inflammatory drugs and spontaneous abortions. Can Med Assoc J 2014; 186:E177-E182.

-97 Edwards DR, Aldridge T, Baird DD, Funk MJ, Savitz DA, Hartmann KE: Periconceptional over-the-counter nonsteroidal antiinflammatory drug exposure and risk for spontaneous abortion. Obstet Gynecol 2012; 120:113-122.

\$9 Park-Wyllie L, Mazzotta P, Pastuszak A, Moretti ME, Beique L, Hunnisett L, et al: Birth defects after maternal exposure to corticosteroids: prospective cohort study and meta-analysis of epidemiological studies. Teratology 2000;62:385-392.

\$9 Gur C, Diav-Citrin O, Shechtman S, Arnon J, Ornoy A: Pregnancy outcome after first trimester exposure to corticosteroids: a prospective controlled study. Reprod Toxicol 2004;18:93-101.

100 Bay Bjorn AM, Ehrenstein V, Hundborg $\mathrm{HH}$, Nohr EA, Sorensen HT, Norgaard M: Use of corticosteroids in early pregnancy is not associated with risk of oral clefts and other congenital malformations in offspring. Am J Ther 2014;21:73-80.

101 Hviid A, Molgaard-Nielsen D: Corticosteroid use during pregnancy and risk of orofacial clefts. Can Med Assoc J 2011;183:796804.

102 Lewis GJ, Lamont CA, Lee HA, Slapak M: Successful pregnancy in a renal transplant recipient taking cyclosporin A. BMJ 1983; 286:603.

-103 Burrows DA, O’Neil TJ, Sorrells TL: Successful twin pregnancy after renal transplant maintained on cyclosporine A immunosuppression. Obstet Gynecol 1988;72:459-461.

104 Flechner SM, Katz AR, Rogers AJ, Van Buren C, Kahan BD: The presence of cyclosporine in body tissues and fluids during pregnancy. Am J Kidney Dis 1985;5:60-63.

105 Zheng S, Easterling TR, Hays K, Umans JG, Miodovnik M, Clark S, et al: Tacrolimus placental transfer at delivery and neonatal exposure through breast milk. Br J Clin Pharmacol 2013;76:988-996.

106 Bar Oz B, Hackman R, Einarson T, Koren G: Pregnancy outcome after cyclosporine therapy during pregnancy: a meta-analysis. Transplantation 2001;71:1051-1055.

-107 Lamarque V, Leleu MF, Monka C, Krupp P: Analysis of 629 pregnancy outcomes in transplant recipients treated with Sandimmun. Transplant Proc 1997;29:2480.

108 Gerosa M, Meroni PL, Cimaz R: Safety considerations when prescribing immunosuppression medication to pregnant women. Expert Opin Drug Saf 2014;13:1591-1599.

109 Jain AB, Reyes J, Marcos A, Mazariegos G, Eghtesad B, Fontes PA, et al: Pregnancy after liver transplantation with tacrolimus immunosuppression: a single center's experience update at 13 years. Transplantation 2003;76: 827-832.
110 Jain AB, Shapiro R, Scantlebury VP, Potdar S, Jordan ML, Flohr J, et al: Pregnancy after kidney and kidney-pancreas transplantation under tacrolimus: a single center's experience. Transplantation 2004;77:897-902.

111 Garcia-Donaire JA, Acevedo M, Gutierrez MJ, Manzanera MJ, Oliva E, Gutierrez E, et al: Tacrolimus as basic immunosuppression in pregnancy after renal transplantation. A single-center experience. Transplant Proc 2005;37:3754-3755.

112 Christopher V, Al-Chalabi T, Richardson PD, Muiesan P, Rela M, Heaton ND, et al: Pregnancy outcome after liver transplantation: a single-center experience of 71 pregnancies in 45 recipients. Liver Transplant 2006;12:1138-1143.

-113 Kainz A, Harabacz I, Cowlrick IS, Gadgil SD, Hagiwara D: Review of the course and outcome of 100 pregnancies in 84 women treated with tacrolimus. Transplantation 2000; 70:1718-1721.

114 Paziana K, Del Monaco M, Cardonick E, Moritz M, Keller M, Smith B, et al: Ciclosporin use during pregnancy. Drug Saf 2013;36: 279-294.

115 Di Paolo S, Schena A, Morrone LF, Manfredi G, Stallone G, Derosa C, et al: Immunologic evaluation during the first year of life of infants born to cyclosporine-treated female kidney transplant recipients: analysis of lymphocyte subpopulations and immunoglobulin serum levels. Transplantation 2000;69:2049-2054.

-116 Biggioggero M, Borghi MO, Gerosa M, Trespidi L, Cimaz R, Meroni PI: Immune function in children born to mothers with autoimmune diseases and exposed in utero to immunosuppressants. Lupus 2007;16:651-656.

-117 Motta M, Ciardelli L, Marconi M, Tincani A, Gasparoni A, Lojacono A, et al: Immune system development in infants born to mothers with autoimmune disease, exposed in utero to immunosuppressive agents. Am J Perinatol 2007;24:441-447.

118 Jain A, Venkataramanan R, Fung JJ, Gartner JC, Lever J, Balan V, et al: Pregnancy after liver transplantation under tacrolimus. Transplantation 1997;64:559-565.

119 Cochat P, Decramer S, Robert-Gnansia E, Dubourg L, Audra P: Renal outcome of children exposed to cyclosporine in utero. Transplant Proc 2004;36(suppl):208S-210S.

120 Nulman I, Sgro M, Barrera M, Chitayat D, Cairney J, Koren G: Long-term neurodevelopment of children exposed in utero to cyclosporine after maternal renal transplant. Paediatr Drugs 2010;12:113-122.

121 Merlob P, Stahl B, Klinger G: Tetrada of the possible mycophenolate mofetil embryopathy: a review. Reprod Toxicol 2009;28:105108.

122 Anderka MT, Lin AE, Abuelo DN, Mitchell AA, Rasmussen SA: Reviewing the evidence for mycophenolate mofetil as a new teratogen: case report and review of the literature. Am J Med Genet A 2009;149A:1241-1248.
123 Hoeltzenbein M, Elefant E, Vial T, FinkelPekarsky V, Stephens S, Clementi M, et al: Teratogenicity of mycophenolate confirmed in a prospective study of the European Network of Teratology Information Services. Am J Med Genet A 2012;158A:588-596.

124 Coscia LA, Constantinescu S, Moritz MJ, Frank AM, Ramirez CB, Maley WR, et al: Report from the National Transplantation Pregnancy Registry (NTPR): outcomes of pregnancy after transplantation. Clin Transpl 2010;65-85.

125 Rigourd V, de Villepin B, Amirouche A, Bruneau A, Seraissol P, Florent A, et al: Ibuprofen concentrations in human mature milk - first data about pharmacokinetics study in breast milk with AOR-10127 'Antalait' study. Ther Drug Monit 2014;36:590596.

126 Ost L, Wettrell G, Bjorkhem I, Rane A: Prednisolone excretion in human milk. J Pediatr 1985;106:1008-1011.

127 Greenberger PA, Odeh YK, Frederiksen MC, Atkinson AJ Jr: Pharmacokinetics of prednisolone transfer to breast milk. Clin Pharmacol Ther 1993;53:324-328.

128 American Academy of Pediatrics Committee on Drugs: Transfer of drugs and other chemicals into human milk. Pediatrics 2001; 108:776-789.

129 Osadchy A, Koren G: Cyclosporine and lactation: when the mother is willing to breastfeed. Ther Drug Monit 2011;33:147-148.

130 Moretti ME, Caprara D, Coutinho CJ, Bar$\mathrm{Oz} \mathrm{B}$, Berkovitch M, Addis A, et al: Fetal safety of loratadine use in the first trimester of pregnancy: a multicenter study. J Allergy Clin Immunol 2003;111:479-483.

131 Mazzuoccolo LD, Andrada R, Pellerano G, Neglia V, Abeldano A: Levels of cyclosporine in breast milk and passage into the circulation of the infant of a mother with psoriasis. Int J Dermatol 2014;53:355-356.

132 French AE, Soldin SJ, Soldin OP, Koren G: Milk transfer and neonatal safety of tacrolimus. Ann Pharmacother 2003;37:815-818.

133 Gardiner SJ, Begg EJ: Breastfeeding during tacrolimus therapy. Obstet Gynecol 2006; 107:453-455.

134 Center for Disease Control and Prevention: Guidelines for vaccinating pregnant women 2013. http://www.cdc.gov/vaccines/pubs/ downloads/b_preg_guide.pdf (accessed March 10, 2015).

135 Center for Disease Control and Prevention: Pregnancy and whooping cough. http:// www.cdc.gov/pertussis/pregnant/mom/getvaccinated.html.

136 Center for Disease Control and Prevention: Breastfeeding and vaccination recommendations. http://www.cdc.gov/breastfeeding/ recommendations/vaccinations.htm (accessed March 10, 2015). 